ACTA MYCOLOGICA

Vol. 49 (1): 79-85

2014
Dedicated to Professor Maria Ławrynowicz on the occasion of the 45th anniversary of her scientific activity

DOI: $10.5586 / \mathrm{am} .2014 .007$

\title{
Flammulina ononidis - first record in Poland
}

\author{
JANUSZ ŁUSZCZYŃSKI, BOŻENA ŁUSZCZYŃSKA, \\ AGNIESZKA TOMASZEWSKA, KINGA SOBAŚ, \\ MAEGORZATA KOSTRZEWA and KATARZYNA GRUDZIEŃ
}

\author{
Department of Botany, Institute of Biology, Jan Kochanowski University \\ Świętokrzyska 15, PL-25-406 Kielce, jluszcz@ujk.kielce.pl
}

Łuszczyński J., Łuszczyńska B., Tomaszewska A., Sobaś K., Kostrzewa M., Grudzień K.: Flammulina ononidis - first record in Poland. Acta Mycol. 49 (1): 79-85, 2014.

The authors present a first record of Flammulina ononidis in Poland. This species was characterized in respect of macro- and micromorphological features, which were illustrated with the original figures and photographs. The habitat conditions of the recorded site were also described. A short discussion concerning the similar species and the ecology and threats of presented fungus species is provided.

Key words: fungi, Basidiomycota, Nida Basin, Ononis spinosa, xerothermic grasslands

\section{INTRODUCTION}

The genus Flammulina numbers about 15 species, of which in Europe according to Horak (2005) five, Petersen et al. (on-line) seven species, but when Pérez-Butrón and Fernández-Vicente (2007) described $F$. cephalariae the number of species is currently eight. In Poland, up to now, were known only two species $-F$. velutipes and F. fennae (Wojewoda 2003). In 2012 in Poland the first site of another species of this genus namely $F$. ononidis was recorded. This taxon, mostly known from Europe, was the first time described by Arnolds (1977), in Germany.

The aim of this article is the presentation and description of $F$. ononidis first site in Poland, with a detailed description of the macro- and micromorphological features, ecology, distribution and threat.

\section{MATERIAL AND METHODS}

In November and December 2012 more than 50 Flammulina ononidis fruitbodies were collected, and the preparations were made from both the fresh and dry material. The 
fruitbodies were dried for 24 hours in the oven in temperature $39^{\circ} \mathrm{C}$. The microscopic features were observed with the light microscope using the standard chemical reagents, $10 \% \mathrm{KOH}$ and floxine. The spores were measured in the sample of 50 spores obtained from 5 fruitbodies. The drawings of the spores and hyphae, pileocystidia and ixohyphidia were made based on the original photographs taken during the microscopic observations. The dried fruitbodies were deposited in the Fungarium of the Faculty of Mathematics and Science, Jan Kochanowski University in Kielce.

\section{RESULTS}

Description of the fruitbody. The fruitbody cap in the mature phase is flat-convex or flat, 15-45 mm in diameter, shiny, in a fresh state viscid, hygrophanous, at the cap edge the gills can be seen through, and in the old fruitbodies the cap is distinctly striped. The edges are from yellow-brown to golden-brown, changing in the direction of top, firstly into bright orange, and later on the top into bright brown, cinnamon-brown, dark carmel to rust-brown (Figs 1-4). The caps of young fruitbodies are semispherical, slightly convex, golden-brown, bright brown-orange, elastic. The stem measures $30-85 \times 2.5-3.5 \mathrm{~mm}$, cylindrical, ending at the bottom part root like or spindle-shaped. The surface velvety. In the upper part, towards the gills, almost white or from creamy to bright yellow. The stipe colour is changing downwards, from bright lemon-yellow, through bright brown, and chocolate brown at the base, particularly in the mature fruitbodies. The stem inside empty. The gills are bright, white-creamy, but near to the edge the cap with an orange tint, 3-5 mm wide, of different length, adnexed, moderately thicken, with a straight and complete edge. The flesh elastic, in the cap pale yellow, in the upper part of stem whitish, in the bottom part particularly at the base wax-yellow, the taste mild, the smell indistinct.

The basidia narrowly club like, four-spores, 28-34 x 6.5-7 $\mu \mathrm{m}$. The spore mass white, cream-white. The spores from wide eliptical to almost almond like with two large or numerous different size drops of the fat, colourless and smooth, (9.45)10.8$13.5 \times 4.7-6 \mu \mathrm{m}$ in size (Fig. 5). Pleurocystidia thin-walled 40-65 x 11.5-17.5 $\mu \mathrm{m}$, of different shape, club like elongated, eliptical, inversely club like. Cheilocystidia numerous, similar to the pleurocystidia. Pileipellis made of the ixohyphidia and pileocystidia. The ixohyphidia thick-walled, branched either tree like or coral like or not branched, measuring 30-75 x 3.5-6.7 $\mu \mathrm{m}$ (Fig. 6). The pileocystidia narrowly lageniform, 68-135 x 8.1-12 $\mu \mathrm{m}$, thick-walled, at the base sometimes bent like letter "S". The stem surface covered with the caulocystidia and cylindrical thin-walled hyphae. The caulocystidia are similar to the pileocystidia but they are slightly wider and more swelled. The thin-walled hyphae are moniliform and slightly constricted towards the top, often with short terminal cells. The hyphae in the stem upper part thin-walled and colourless, in the bottom part thick-walled with brown pigment.

THE SITE DESCRIPTION. The fruitbodies of Flammulina ononidis were found in the Nida Basin, $1 \mathrm{~km}$ west of the Pińczów town (square ATPOL FE 13), in the phytocenosis of the alliance Cirsio-Brachypodion, in Inuletum ensifoliae and ThalictroSalvietum, which cover the southern slope of the limestone hills referred to as the "Góry Pińczowskie". The fruitbodies were growing singly and in small groups on the 

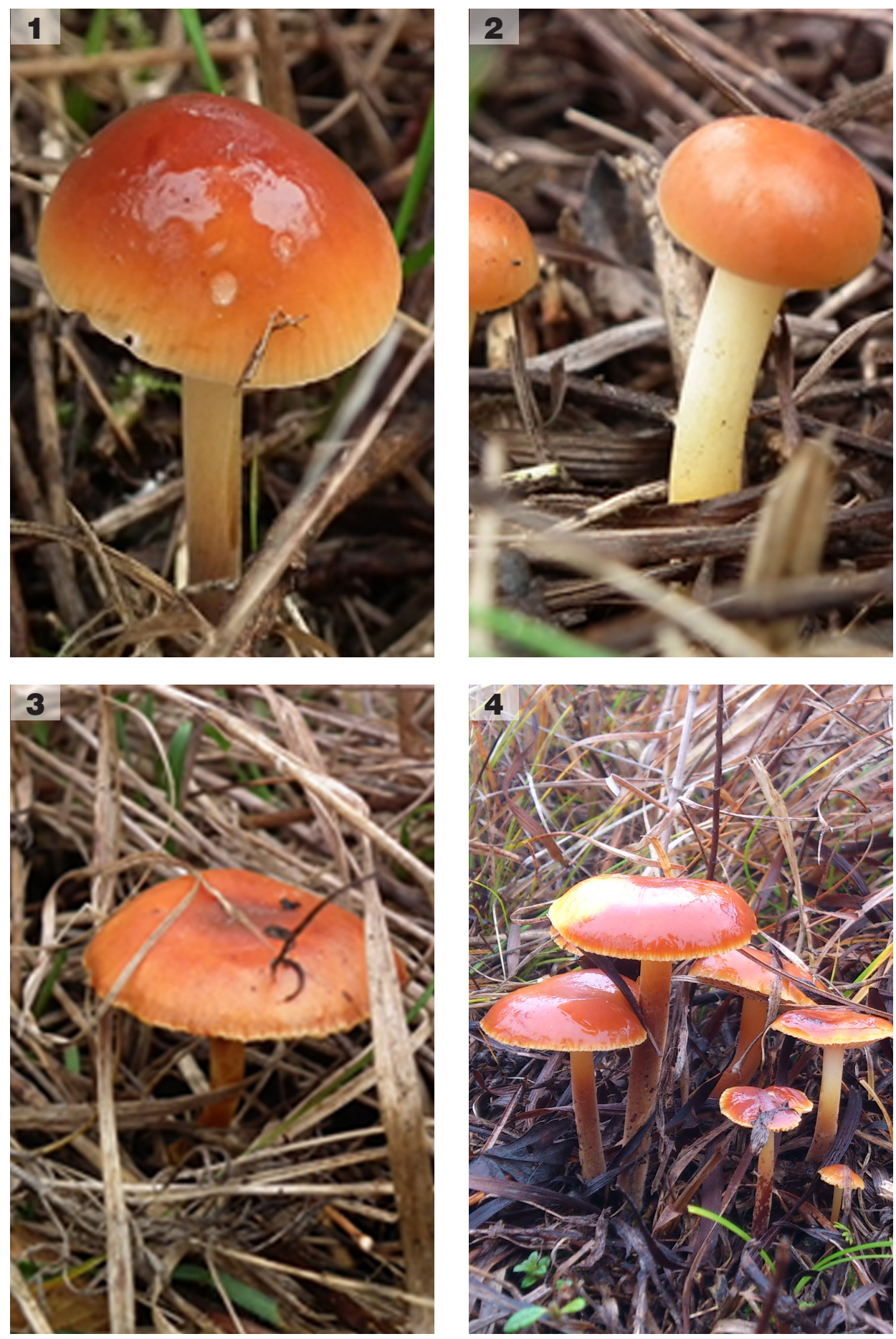

Figs 1-4. Flammulina ononidis on xerothermic grassland (Photos 1-3 by K. Sobaś, Photo 4 by A. Tomaszewska). 


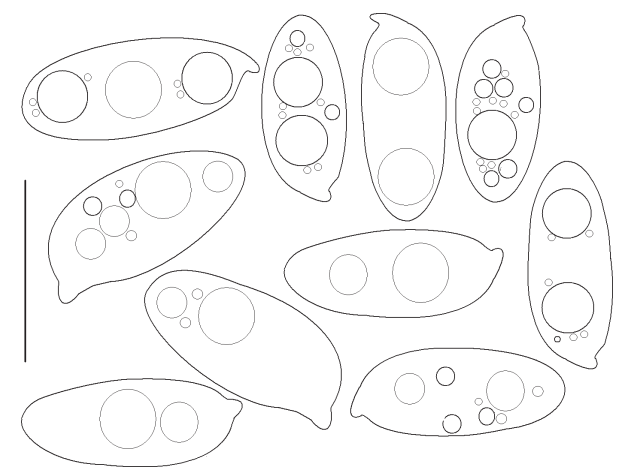

Fig. 5. Flammulina ononidis: spores. Scale bar $=10 \mu \mathrm{m}$.
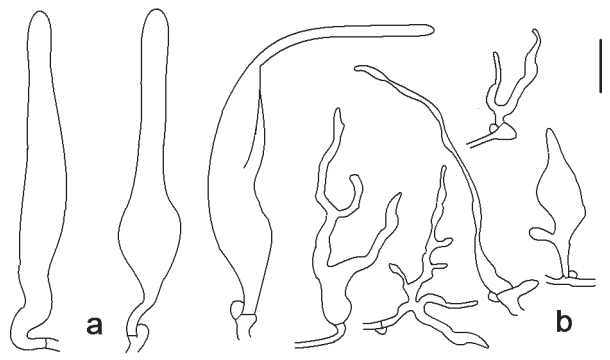

Fig. 6. Flammulina ononidis: a - pileocystidia, $\mathrm{b}$ - ixohyphidia. Scale bar $=10 \mu \mathrm{m}$.

soil, in the immediate neighbourhood of Ononis spinosa. The role of Ononis spinosa in the mentioned grasslands is particularly significant considering its quantitative participation. These are the phytocenosis where Ononis spinosa covers the patches in the density from $20 \%$ to $30 \%$. The areas of these communities up to not long ago were still grazed by the household cattle. Presently the grazing since five years was completely ceased. The composition and the plant species participation in the investigated communities are illustrated by the phytosociological relevés.

Inuletum ensifoliae, Ch.Ass.: Carlina onopordifolia +.2 , Inula ensifolia 5.5, Linum hirsutum + ; others: Achillea pannonica + , Adonis vernalis + , Asperula cynanchica + , Avenastrum pratense + , Brachypodium pinnatum 1.1, Carlina vulgaris + , Centaurea scabiosa + , Carex humilis 2.2, Euphorbia cyparissias + , Festuca rupicola +.2 , Galium verum 1.2, Melampyrum arvense 1.1, Ononis spinosa 2.2, Peucedanum cervaria 2.2, Ranunuculus bulbosus + , Salvia pratensis + , Sanguisorba minor + , Seseli annuum + , Thesium linophyllon + , Thymus pannonicus +.2 , Th. marschallianus 1.2.

Thalictro-Salvietum: Elymus hispidus subsp. hispidus 2.2, Adonis vernalis 1.1, Agrimonia eupatoria 1.2, Allium oleraceum + , Anemone sylvestris 1.2, Brachypodium pinnatum 2.3, Carex humilis +.2 , Coronilla varia + , Erigeron acer + , Euphorbia cyparissias +.2 , Festuca rupicola +.2 , Fragaria viridis +.2 , Galium verum 2.3, Geranium sanguineum +, Gypsophila fastigiata 1.2, Medicago falcata +, Ononis spinosa 3.3, Plantago lanceolata + , Salvia pratensis 3.3, Salvia verticillata 1.2, Seseli annuum +, Thalictrum minus 2.2, Thesium linophyllon 1.2.

The fruitbodies were observed and collected from November 2012 till January 2013. It is interesting that the mycelium was still producing new fruitbodies in January, despite of earlier frosts up to $-15^{\circ} \mathrm{C}$, at the turn of November and December 2012.

General distribution. Flammulina ononidis is known first of all from the European countries. It was recorded up to now from: Austria (Krisai-Greilhuber 1999), Croatia (Tkalčec et al. 2005), Czech Republic (Antonín 2006), Belgium (Walleyn, Vandeven 2006), Denmark (Petersen, Vesterholt 2003), France (Anonymus 1, 2, online), Germany (Arnolds 1977; Krieglsteiner 1978), Hungary (Babos 1968; Cetto 1994), Estonia (Urbonas et al. 1986), Italy (Petersen et al., on-line), Russia (Petersen et al., on-line), Slovakia (Ripková et al. 2008) and Turkey (Pekşen, Karaca 2003). 


\section{DISCUSSION}

Flammulina ononidis is the species mainly connected with Ononis spinosa. The majority of until now published data refer to this plant species. However, it is interesting that, Urbonas et al. (1986) collected the fruitbodies of $F$. ononidis on Trifolium pratense. Perhaps it is possible to collect $F$. ononidis fruitbodies on the other Fabaceae family plants. It is curious that Redhead and Petersen (1999) in California, found F. velutipes var. lupinicola on Lupinus arboreus. Whereas Pérez-Butrón and Fernández-Vicente (2007) described from the northern Spain a new species F. cephalariae of which the mycelium were developing on the roots of Cephalaria leucantha (Dipsacaceae). These examples provide an interesting perspective on the ecology of some species of the genus Flammulina and their connection with the host plants. There is a striking morphological similarity of some Flammulina species and this can pose a quite serious problem when identifying species in the field. Distinctive differences between the species are marked at the level of the microscopic structures, in particular of the features referring to the structure of the cap skin and the size of spores. In table 1 are presented the spores sizes for the selected taxa of Flammulina genus. The fruitbodies of these taxa morphologically are very similar.

The spores size of Flammulina ononidis collected in Pińczów are almost precisely the same as those presented by Arnolds (1977) and Bas (1983).

Information referring to the ecology of $F$. ononidis are also concurrent with our observations referring to the investigated site in Pińczów. According to Antonín (2006), Bas (1995), Hagara et al. (2005), Klán (1978), (Kotlaba 1995), Ripková et al. (2008) it is a species which prefers the habitats on the limestone soils in the plant communities belonging to the alliances Bromion erecti and Cirsio-Brachypodion pinnati from Festuco-Brometea class. A very important element referring to the habitat demands is Ononis spinosa as the host plant. This plant prefers dry, sufficiently

Table 1

Comparison of spore size of the similar species from the Flammulina genus

\begin{tabular}{|c|c|c|c|c|c|}
\hline Species & Authors & Size of spores & $\mathrm{Q}$ & av. Q & Plant host \\
\hline F. ononidis & Arnolds (1977) & $\begin{array}{c}\text { (7.5) } 8.5-13(14) \times \\
\text { (4) } 4.5-6\end{array}$ & . & $\because$ & Ononis spinosa \\
\hline F. ononidis & Bas (1983) & $\begin{array}{r}(7.5) 8.5-12.5(14) \\
\times(4) 4.5-5.5(6)\end{array}$ & $\begin{array}{c}(1.6) \\
1.7-2.45\end{array}$ & $1.9-2.3$ & Ononis spinosa \\
\hline F. ononidis & Horak (2005) & $8.5-13 \times 4.5-5$ & & & Ononis spinosa \\
\hline F. ononidis & Ripková (2008) & $\begin{array}{c}(8.6) 9.4-10.6 \\
(11.2) \times(4.1) \\
4.3-5.2(6)\end{array}$ & $\begin{array}{c}(1.76) \\
1.94-2.28 \\
(2.43)\end{array}$ & 2.11 & Ononis spinosa \\
\hline $\begin{array}{l}\text { F. velutipes } \\
\text { var. } \\
\text { lupinicola }\end{array}$ & $\begin{array}{l}\text { Redhead and } \\
\text { Petersen (1999) }\end{array}$ & $\begin{array}{c}7-14.8 \times 3.7-6.6 \\
\text { av. } 4.5-5.4\end{array}$ & $(2.10)$ & . & Lupinus arboreus \\
\hline $\begin{array}{l}F \\
\text { cephalariae }\end{array}$ & $\begin{array}{l}\text { Pérez-Butrón } \\
\text { and } \\
\text { Fernández- } \\
\text { Vicente }(2007)\end{array}$ & $\begin{array}{c}(9.2) 12-16.8(17) \\
x(5) 5.6-7.6(8)\end{array}$ & 2 & & $\begin{array}{l}\text { Cephalaria } \\
\text { leucantha }\end{array}$ \\
\hline F. velutipes & $\begin{array}{l}\text { Petersen et al. } \\
\text { (on-line) }\end{array}$ & $6-9.5 \times 3-4$ & . & $2-2.3$ & $\begin{array}{l}\text { hardwood trees, } \\
\text { mainly Salix, } \\
\text { Populus, Alnus }\end{array}$ \\
\hline F. elastica & $\begin{array}{l}\text { Petersen et al. } \\
\text { (on-line) }\end{array}$ & $8-11.5 \times 3-4$ & . & $2.5-3$ & $\begin{array}{l}\text { hardwood trees, } \\
\text { mainly Salix }\end{array}$ \\
\hline
\end{tabular}


sunny habitats, growing on different soils from acid and rather loose sands to the soils more heavy and rich in $\mathrm{CaCO}_{3}$. In Poland it is rather rare species, mostly connected with the xerothermic habitats. According to the cited authors $F$. ononidis was also found on the limestone sands of dunes and mentioned from the calcareous dunes and river dikes.

ENDANGERMENTS. Flammulina ononidis belongs to the endangered fungi in Austria (Krisai-Greilhuber 1999), Croatia (Tkalčec et al. 2005), Czech Republic (Holec, Beran 2006) and Germany (Benkert et al. 1996). In Poland the endangered problem for $F$. ononidis is similar to that in the above mentioned countries. This results from the discontinuation of traditional forms of exploitation of the xerothermic grasslands. As a result of this the grasslands are subjected to succession and are overgrown by the shady shrubby brushwoods. An effective form of both the fungus and hose plant protection is an active protection of the habitats and the types of communities, which are conducive for development of $F$. ononidis and Ononis spinosa. The effective protective interventions should be rather intensive grazing with the home animals and cutting out the appearing brushwoods.

\section{REFERENCES}

Anonymus 1 (on-line). La modernisation des zones naturelles d'intérêt ecologique, faunistique et floristique en région Nord Pas-de-Calais. http://www.nord-pas-de-calais.ecologie.gouv.fr/IMG/pdf/informations_generales-2.pdf

Anonymus 2 (on-line). Flammulina ononidis Arnolds. http://www.pharmanatur.com/Mycologie/Flammulina\%20ononidis.htm

Antonín V. 2006. Flammulina ononidis Arnolds. (In:) J. Holec, M. Beran (eds). Červený seznam hub (makromycetů) České republiky. Příroda 24: 116.

Arnolds E. 1977. Einige Pilze eines Halbtrockenrasen bei Detmold (Westfalen). Westfäl. Pilzbriefe 11 (3/4): 29-39.

Babos M. 1968. Adatok Magyarország ritka kalaposgombáinak és pöfetegféléinek ismeretéhez III. A budakalászi legelögombái. Fragm. Bot. 6: 23-40.

Bas C. 1983. Flammulina in western Europe. Persoonia 12: 51-66.

Bas C. 1995. Genus Flammulina P. Karst. (In:) C. Bas, Th. W., Kuyper, M. E. Noordeloos and E. C. Vellinga (eds). Flora agaricina neerlandica, 3: 170-173, Rotterdam.

Benkert D., Dörfelt H., Hardtke H.J., Hirsch G., Kreisel H., Krieglsteiner G.J., Lüderitz M., Runge A., Schmidt H., Schmitt J.A., Winterhoff W., Wöldecke K., Zehfuss H.D. 1996. Rote Liste der Großpilze Deutschlands. [In:] G. Ludwig and M. Schnittler (eds). Rote Listen gefährdeter Pflanzen Deutschlands, Schriftenreihe für Vegetationskunde 28: 377-426.

Cetto B. 1994. I funghi dal vero. 6. Trento, 722 pp.

Hagara L., Antonín V., Baier J. 2005. Vel'ký atlas húb. Praha, 432 pp.

Holec J., Beran M. (eds). 2006. Červený seznam hub (makromycetů) České republiky. Příroda 24: 1-282.

Horak E. 2005. Röhrlinge und Blätterpilze in Europa. Elsevier Spectrum Academisher Verlag, 555 pp.

Klán J. 1978. Flammulina ononidis Arnolds, ein besonderer Steppen-Samtfussrübling in der Tschechoslowakei. Česká Mykol. 32: 205-214.

Kotlaba F. (ed.). 1995. Červená kniha ohrozených a vzácnych druhov rastlín a živočíchov SR a ČR. 4. Sinice a riasy, huby, lišajníky, machorasty. Bratislava, 224 pp.

Krieglsteiner G.J. 1978. Der Hauheckel-Rübling, Flammulina ononidis Arnolds 1977 auch in Süddeutschland. Südwestdt. Pilzrundsch. 14 (2): 1-7.

Krisai-Greilhuber I. 1999. Rote Liste gefährdeter Großpilze Österreichs. (In:) H. Niklfeld (ed.). Rote Listen gefährdeter Pflanzen Österreichs, Bundesministerium für Umwelt, Jugend und Familie, p. 229-266, Graz.

Pérez-Butrón J.L., Fernández-Vicente J. 2007. Una nueva especie de Flammulina P. Karsten, F. cephalariae (Agaricales) encontrada en España. Revista Catalana de Micologia 29: 81-91. 
Pekşen A., Karaca G. 2003. Macrofungi of Samsun Province. Turkish J. Bot. 27: 173-184.

Petersen R.H., Hughes K.W., Redhead S.A. (on-line). The genus Flammulina, a Tennessee tutorial. http:// www.bio.utk.edu/mycology/Flammulina/default.html

Petersen J.H, Vesterholt J. 2003. De danske svampenavne - en kommenteret navneliste. 76 p. Ebeltoft. http://www.mycokey.com/MycokeyDK/DKkeysPDFs/DeDanskeSvampenavne.pdf

Redhead S.A., Petersen R.H. 1999. New species, varieties and combinations in the genus Flammulina. Mycotaxon 71: 285-294.

Ripková S., Adamčík S., Kučera V. 2008. Flammulina ononidis - a new species for Slovakia. Czech Mycol. 60 (2): 221-230.

Tkalčec Z., Mešić A., Matočec N. 2005. Crveni popis gljiva HR. http://www.dzzp.hr/dokumenti_upload/20100414/dzzp201004141250262.pdf

Urbonas V., Kalamees K., Lukin V. 1986. Conspectus florum agaricalium fungorum (Agaricales s. 1.) Lithuaniae, Latviae et Estoniae (Materies 1778-1984 annorum). Vilnius, 138 p.

Walleyn R., Vandeven E. (eds). 2006. Standaardlijst van Basidiomycota en Myxomycota van Vlaanderen en het Brussels Gewest. 143 p. Brussel. www.inbo.be/docupload/3062.pdf

\section{Flammulina ononidis - pierwsze stanowisko w Polsce}

Artykuł prezentuje nowy dla Polski gatunek grzyba Flammulina ononidis. Gatunek ten został scharakteryzowany pod względem jego cech makro- i mikroskopowych, a także warunków siedliskowych, ze szczególnym uwzględnieniem składu fitocenoz w których wyrastał. Nowe stanowisko grzyba zostało znalezione na wzgórzach kserotermicznych koło Pińczowa w płatach Inuletum ensifoliae i Thalictro-Salvietum (klasa Festuco-Brometea), gdzie wyrastał na korzeniach Ononis spinosa. Przedstawiono krótką dyskusję dotyczącą gatunków podobnych oraz ekologii i zagrożeń prezentowanego gatunku grzyba. 